\title{
KAJIAN EPIDEMIOLOGI KEJADIAN DEMAM BERDARAH DENGUE DI WILAYAH KERJA PUSKESMAS ROWOSARI KOTA SEMARANG
}

\author{
Asih Prasetyowati ${ }^{1}$, Roro Kushartanti ${ }^{2}$ \\ ${ }^{1}$ Dosen Prodi Rekam Medis dan Informasi Kesehatan STIKES HAKLI Semarang \\ ${ }^{2}$ Dosen Prodi Kesehatan Masyarakat STIKES HAKLI Semarang \\ *email : rorokushartanti@gmail.com
}

\begin{abstract}
Aedes aegypti mosquito is a vector that causes Dengue Hemorrhagic Fever. DHF is one of the top 10 diseases in Indonesia and is also one of the top 10 diseases in the Semarang city. The spread of DHF tends to increase both in the number of events and in the area and sporadically an extraordinary event (KLB) always occurs every year. This study aims to examine epidemiologically DHF events that occur almost every year. This research is a quantitative study, which was conducted in an observational descriptive manner with a retrospective time approach. The incidence of DHF in the Rowosari Community Health Center is mostly found in the male population (56\%) and the most age group (65\%) is 5-14 years. The sub-district with the highest IR DBD (161.86/ 100000) is the Kramas sub-district. The peak incidence of DHF is April - May in 2019. Based on the DHF epidemiological study, it is recommended that "Eradication Mosquitos Nest" (PSN) continue to carry out its activities in collaboration with Gasurkes. Prevention of mosquito bites is further enhanced by the school age population. PSN activities are not only limited to the indoor environment, but also the external environment such as public places, vacant land and houses. The community service program to clean the surrounding environment needs to be maximized, for example with Clean Friday Activities.

Keywords: Dengue Hemorragic Fever, Epidemiology Studies, Community Health Centre.
\end{abstract}

\begin{abstract}
ABSTRAK
Nyamuk Aedes aegypti adalah vektor yang menyebabkan Demam Berdarah Dengue. DBD adalah salah satu dari 10 penyakit teratas di Indonesia dan juga salah satu dari 10 penyakit teratas di kota Semarang. Penyebaran DBD cenderung meningkat baik dalam jumlah acara dan di daerah dan secara sporadis kejadian luar biasa (KLB) selalu terjadi setiap tahun. Penelitian ini bertujuan untuk memeriksa kejadian DBD secara epidemiologis yang terjadi hampir setiap tahun. Penelitian ini adalah penelitian kuantitatif, yang dilakukan secara deskriptif observasional dengan pendekatan waktu retrospektif. Kejadian DBD di Rowosari Community Health Center sebagian besar ditemukan pada populasi pria (56\%) dan kelompok usia terbanyak (65\%) adalah 5-14 tahun. Kecamatan dengan IR DBD tertinggi (161,86 / 100000) adalah kecamatan Kramas. Puncak insiden DBD adalah April - Mei tahun 2019. Berdasarkan studi epidemiologi DBD, direkomendasikan bahwa "Pemberantasan Sarang Nyamuk" (PSN) terus melakukan kegiatannya bekerja sama dengan Gasurkes. Pencegahan gigitan nyamuk semakin ditingkatkan oleh populasi usia sekolah. Kegiatan PSN tidak hanya terbatas pada lingkungan indoor, tetapi juga lingkungan eksternal seperti tempat umum, tanah kosong dan rumah. Program layanan masyarakat untuk membersihkan lingkungan sekitar perlu dimaksimalkan, misalnya dengan Kegiatan Jumat Bersih.
\end{abstract}

Kata kunci: Demam Berdarah Dengue, Studi Epidemiologi, Puskesmas. 


\section{PENDAHULUAN}

Demam Berdarah Dengue adalah penyakit infeksi karena virus dengue yang ditularkan melalui gigitan Nyamuk Aedes Aegypti. Nyamuk ini yang paling cepat berkembangbiak di dunia dan menyebabkan sebanyak 390 juta orang terinfeksi setiap tahun. DBD memiliki gejala antara lain nyeri pada hari secara terus menerus, perdarahan pada mulut, gusi, hidung, atau memar pada kulit (Pusdatin Kemenkes RI, 2017).

Berdasarkan data dari Direktorat Jenderal Pencegahan dan Pengendalian Penyakit, Kementerian Kesehatan (Kemenkes) RI, distribusi penyakit suspek DBD sejak minggu pertama 2018 hingga minggu pertama 2019 tertinggi ada di Jawa Timur dengan jumlah suspek DBD 700 orang, diikuti Jawa Tengah 512 orang, dan Jawa Barat 401 orang (Kemenkes RI, 2018). Pada tahun 2018, Incidence Rate (IR) DBD Jawa Tengah sebesar 10,2 per 10000, Case Fatality Rate (CFR) DBD 1,05\%. Adapun IR DBD Kota Semarang 5,43 per 10000 dan CFR DBD 1,03 persen (Dinkes Provinsi Jateng, 2018).

Jumlah penderita DBD di Kota Semarang Tahun 2018 turun menjadi 103 kasus dari 299 kasus. Incidence Rate DBD juga terjadi penurunan yang signifikan dari yang sebelumnya 6,17 pada tahun 2018 . CFR DBD Tahun 2018 menurun, dari 2,7 pada tahun 2017 menjadi 0,97(1 kematian) pada tahun 2018. Urutan IR DBD terbesar di Kota Semarang berturut-turut yaitu Tembalang, Srondol Kulon, Karangrejo, Sampangan, Lamper Lor, Mijen, Brumbungan, Jomblang, Bongsari, dan Meteseh (Dinkes Kota Semarang, 2017).

Puskesmas Rowosari memiliki wilayah kerja di Kecamatan Tembalang yang terdiri dari Kelurahan Bulusan, Kramas, Meteseh, Rowosari, dan Tembalang. Penelitian ini bertujuan untuk mengkaji secara epidemiologis kejadian
DBD yang hampir setiap tahun terjadi. Kajian epidemiologi Penyakit DBD berdasarkan aspek orang, tempat, dan waktu dapat digunakan untuk pembuatan kebijakan dan mengembangkan intervensi kesehatan masyarakat yang berbasis bukti ilmiah dan menentukan sasaran intervensi kesehatan masyarakat (International Conference of Public Health, 2019).

\section{METODE PENELITIAN}

Penelitian ini merupakan studi kuantitatif, yang dilakukan secara deskriptif observatif dengan pendekatan waktu retrospektif (Dahlan, 2011). Variabel penelitian meliputi karakteristik orang, karakteristik tempat, dan karakteristik waktu kejadian Demam Berdarah Dengue, dan Angka Bebas Jentik (ABJ) di Wilayah Kerja Puskesmas Rowosari.

Karakteristik orang meliputi umur dan jenis kelamin. Karakteristik tempat dibagi menurut kelurahan, dan karakteristik waktu dibagi menurut tahun dan bulan kejadian DBD.

Sumber data berasal dari data sekunder Profil Kesehatan Puskesmas Rowosari Semarang Bulan Januari sampai dengan September 2019. Analisa data menggunakan metoda analisa deskriptif yaitu menganalisis data secara naratif, serta data dibandingkan dengan penelitian lain yang sejenis.

\section{HASIL}

Gambaran Geografis dan Kependudukan

Wilayah kerja puskesmas Rowosari terdiri dari 5 kelurahan yaitu Kelurahan Bulusan, Kramas, Meteseh, Rowosari, dan Tembalang. Secara umum wilayah ini merupakan dataran tinggi/perbukitan dengan ketinggian permukaan tanah dari permukaan air laut adalah $20 \mathrm{~m}$. Banyaknya curah hujan rata-rata $200 \mathrm{~mm} /$ tahun. Suhu udara adalah $32-34^{\circ} \mathrm{C}$. Data kependudukan ditunjukkan Tabel 1. 
Tabel 1. Kepadatan Penduduk di Wilayah Kerja Puskesmas Rowosari Kota Semarang

\begin{tabular}{llrrr}
\hline No & Kelurahan & Luas Tanah $\left(\mathrm{m}^{2}\right)$ & Jumlah Penduduk & $\begin{array}{c}\text { Kepadatan } \\
\text { penduduk } \\
\text { (orang/m2) }\end{array}$ \\
\hline 1 & Bulusan & 498.669 & 5903 & 52 \\
2 & Kramas & 392.260 & 3546 & 30 \\
3 & Meteseh & 719.577 & 20251 & 25 \\
4 & Rowosari & 105.320 & 12303 & 59 \\
5 & Tembalang & 304.072 & 6146 & 64 \\
\hline & Jumlah & 2.019 .898 & 48149 & 42 \\
\hline
\end{tabular}

Sumber : Profil puskesmas Rowosari, 2018

Tabel 1 menunjukkan bahwa kelurahan paling padat adalah Tembalang dan kelurahan paling kecil kepadatannya adalah Kramas. Wilayah Kelurahan Tembalang sebagian besar berisi perumahan dan kos-kosan sedangkan Kelurahan Kramas banyak lahan-lahan kosong dan perkebunan.

\section{Karakteristik Penderita DBD}

Karakteristik penderita

DBD berdasarkan jenis kelamin dan umur ditunjukkan dengan grafik 1 dan grafik 2 berikut.

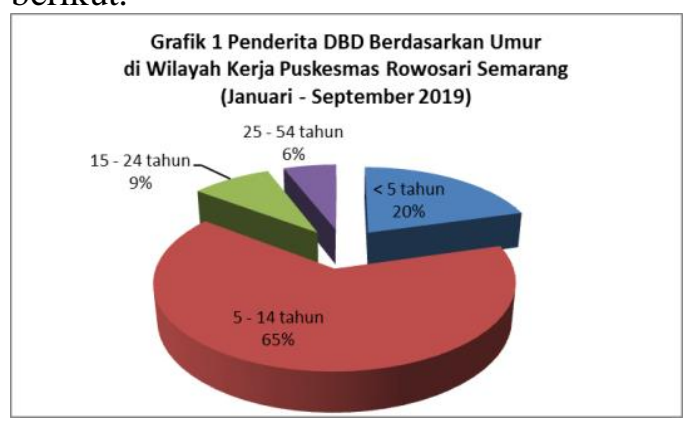

Grafik 1 menunjukkan bahwa sebagian besar penderita DBD berusia 5 - 14 tahun (65\%) dan paling sedikit berusia $25-54$ tahun $(6 \%)$.

Grafik 2 Penderita DBD Berdasarkan Jenis Kelamin di Wilayah Kerja Puskesmas Rowosari Semarang (Januari - September 2019)

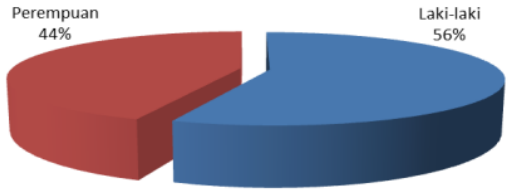

Grafik 2 menunjukkan bahwa sebagian besar penderita DBD adalah lakilaki $(56 \%)$ dan sisanya adalah penderita perempuan (44\%). Hasil penelitian ini sesuai dengan penelitian Murdani (2017) yang menunjukkan prevalensi kejadian DBD di Banyuwangi untuk laki-laki lebih besar dari perempuan. Beberapa perbedaan antara jenis kelamin laki-laki dengan perempuan salah satunya adalah faktor mobilitas. Menurut Kasman dan Ishkak (2018) laki-laki pada dasarnya lebih banyak menghabiskan waktunya di luar rumah, sehingga risiko untuk tergigit nyamuk semakin besar (Suyani, 2018).

Sejalan dengan penelitian Suryani (2018), penderita DBD di Blitar paling banyak berusia 5-14 tahun dan terbanyak jenis kelamin laki-laki. Penelitian Wikrama (2014) di Tegalalang menghasilkan bahwa penderita DBD terbanyak pada laki-laki dan paling banyak berusia 15-24 tahun. Sebaliknya, penelitian oleh Hutagaol (2016) di Binjai menunjukkan bahwa penderita DBD terbanyak pada perempuan (61\%) dan berusia $18-30$ tahun $(46,4 \%)$. Penelitian oleh Permatasari (2018) di RS Patria IKKT menunjukkan penderita DBD terbanyak pada usia 15-14 tahun (35\%) dan penderita terbanyak dengan jenis kelamin laki-laki (61\%). Umur 5-14 tahun memiliki aktivitas cukup tinggi pada siang hari sehingga tingkat kepaparan dengan gigitan nyamuk sangat besar. Nyamuk Aedes Aegypti diketahui memiliki ciri aktivitas pada siang hari. Kelompok umur kurang dari 12 tahun memiliki daya tahan tubuh yang masih rendah dengan aktivitas 
yang tinggi sehingga risiko terkena gigitan nyamuk lebih tinggi (Murdani, 2017)

\section{Kejadian DBD Berdasarkan Tempat}

Kejadian DBD berdasarkan

Kelurahan dan kepadatan penduduk Wilayah Kerja Puskesmas Rowosari dapat dilihat pada grafik berikut.

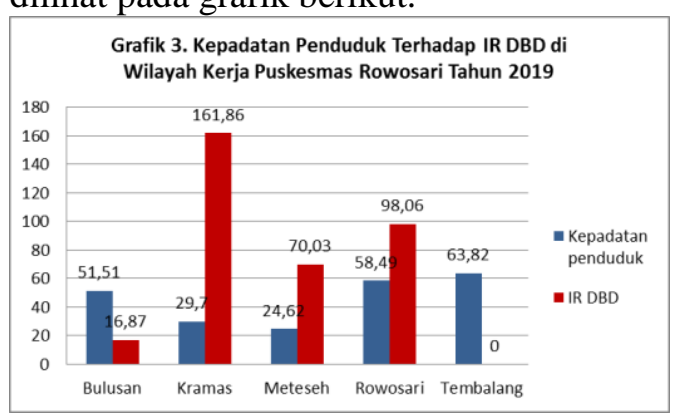

Dari Grafik 3 terlihat bahwa Kelurahan dengan angka IR DBD paling besar adalah Kelurahan Kramas, paling besar kedua adalah Rowosari, kemudian Meteseh, dan Bulusan. Kelurahan yang tidak ada kejadian DBD adalah Kelurahan Tembalang.

Data IR DBD berdasarkan kepadatan penduduk terlihat bahwa IR DBD tertinggi pada Kelurahan Kramas dengan kepadatan penduduk terendah. IR DBD terendah pada Kelurahan Tembalang dengan kepadatan penduduk tertinggi. Kebalikan dari penelitan Chandra (2019), yang menunjukkan bahwa kepadatan penduduk memiliki hubungan dengan kejadian DBD, hubungan tersebut dalam kategori hubungan rendah ( $\mathrm{r}=0,153$ atau $15,3 \%)$ dan berpola positif artinya semakin bertambah kepadatan

penduduk semakin tinggi kemungkinan bertambahnya kejadian DBD (Chandra, 2019).

Hasil penelitian ini sejalan dengan penelitian Syahria (2015) yang menunjukkan bahwa kepadatan penduduk tidak berperan dalam terjadinya penyakit DBD di Kabupaten Minahasa Selatan. Kepadatan penduduk bukan merupakan faktor kausatif, tetapi hanya merupakan salah satu faktor risiko terjadinya DBD. Faktor lain seperti mobilitas penduduk, sanitasi lingkungan, keberadaan kontainer perindukan nyamuk Aedes, kepadatan vektor, tingkat pengetahuan, sikap dan tindakan terhadap penyakit merupakan faktor risiko terhadap kejadian DBD (Syahria, 2015).

Kepadatan penduduk wilayah Puskesmas Rowosari tidak berkaitan dengan kepadatan penduduk. Hal ini disebabkan karena angka bebas jentik yang cukup tinggi yaitu rata-rata di atas $95 \%$. Kelurahan Kramas memiliki lahan yang banyak dimanfaatkan untuk perkebunan sehingga dimungkinkan banyak terdapat tempat perindukan nyamuk. Nyamuk A. aegypti hidup dan berkembang biak di tempat-tempat penampungan air (TPA) untuk keperluan sehari-hari, tanah padat yang mengeras, serta barang-barang bekas di luar rumah seperti: kaleng, botol, ban bekas, potongan bambu, aksila daun, plastik, dan lain sebagainya. Kadangkadang jentik dijumpai dalam talang air, lubang pohon, dan genangan air (Wowor, 2017).

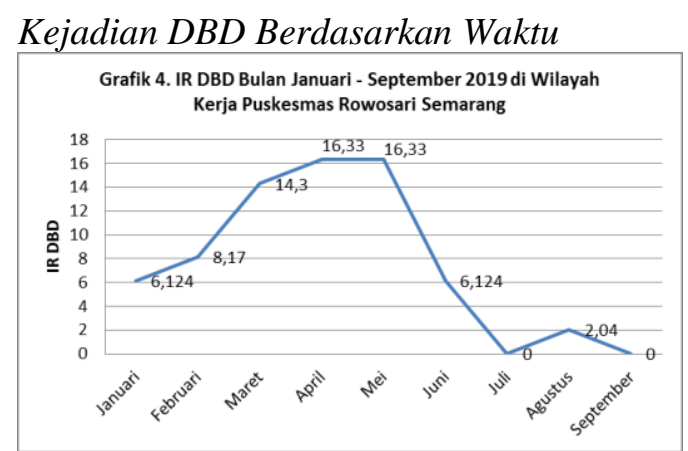

Grafik 4 terlihat bahwa puncak kejadian DBD pada tahun 2019 adalah pada Bulan April - Mei. Pada bulan-bulan tersebut, Kota Semarang masuk pada musim penghujan. Penelitian Chandra (2019) menunjukkan bahwa ada pengaruh yang signifikan antara curah hujan dengan IR DBD. Kepadatan populasi nyamuk A. aegypti akan meningkat di musim hujan. Banyak terdapat genangan air yang merupakan tempat perindukannya sehingga jumlah nyamuk meningkat (Wowor, 2017). Ada kaitan interaktif antara penentu 
Kejadian DBD yaitu virus penyebab dengue, manusia, nyamuk vektor dan lingkungan. Pada musim hujan, jumlah nyamuk akan meningkat dan kelembaban udara yang tinggi menyebabkan meningkatnya aktivitas nyamuk untuk menggigit. Kontak antara nyamuk dengan manusia meningkat karena pada musim hujan orang-orang umumnya lebih banyak tinggal di dalam rumah (Wowor, 2017).

Di bawah ini Grafik yang menggambarkan IR DBD dalam tiga tahun terakhir.

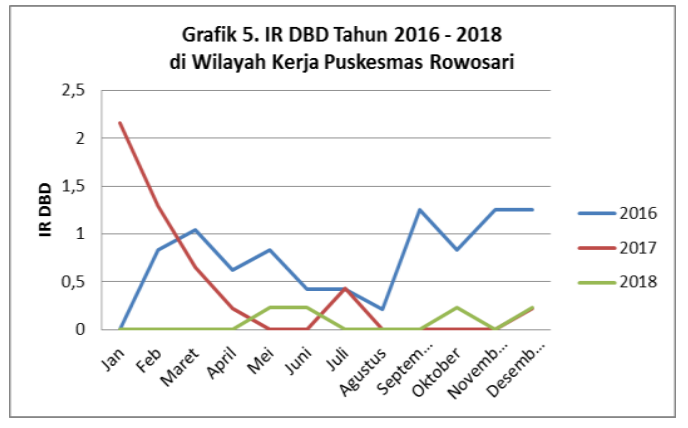

Grafik di atas menunjukkan pola kejadian DBD yang berbeda-beda setiap tahun. Hal ini tergantung dari curah hujan yang terjadi setiap tahunnya. Terjadi pergeseran puncak kejadian DBD dari bulan September - Desember menjadi awal tahun sampai mendekati pertengahan tahun (April - Mei). Secara nasional penyakit DBD di Indonesia setiap tahun terjadi pada buan September s/d Februari. Puncak kejadian DBD pada bulan Desember atau Januari yang bertepatan dengan waktu musim hujan. Untuk kota besar, musim penularan terjadi pada bulan Maret s/d Agustus dengan puncak terjadi pada bulan Juni atau Juli (Wowor, 2017).

Grafik di bawah ini menggambarkan trend kejadian DBD selama lima tahun terakhir setiap Kelurahan dan trend IR DBD selama delapan tahun terakhir.

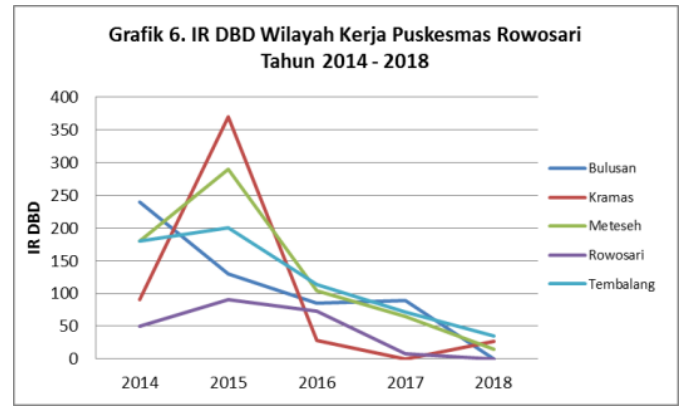

Grafik di atas menunjukkan bahwa selama lima tahun terakhir, angka IR DBD mengalami puncaknya pada tahun 2015 kemudian turun pada tahun-tahun berikutnya. IR DBD tertinggi mencapai puncaknya pada tahun 2015 pada Kelurahan Kramas. Trend IR DBD ditunjukkan pada grafik di bawah ini.

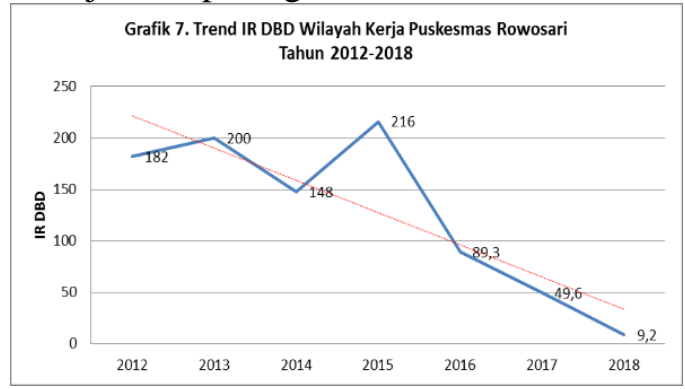

Trend kejadian DBD dalam 7 tujuh tahun terakhir menunjukkan penurunan. Program Pengendalian DBD di Puskesmas Rowosari yang berfokus kepada kinerja petugas pemantau jentik nyamuk telah berhasil menurunkan kejadian DBD. Program ini dibantu dengan adanya pembentukan Petugas Surveilans Kesehatan (Gasurkes) DBD sesuai Perda Kota Semarang Nomor 5 Tahun 2010. Kelurahan Tembalang pada tahun sebelumnya adalah penyumbang IR DBD yang paling tinggi di kota Semarang. Tetapi dengan program pengendalian DBD yang berkelanjutan, angka kejadian DBD dapat terus berkurang (Salsabila, 2018). Dibandingkan dengan tahun 2018, Angka IR DBD sampai bulan September 2019 naik menjadi 69,4/100000. Kenaikan angka kejadian ini harus menjadi perhatian terutama pada Kelurahan Kramas sebagai penyumbang terbesar incidence rate. 
Kaitan Angka Bebas Jentik dengan Kejadian DBD

Keberadaan jentik A. aegypti suatu daerah merupakan indikator terdapatnya populasi nyamuk A. aegyptidi daerah tersebut. Angka Bebas Jentik (ABJ) adalah persentase jumlah rumah atau bangunan yang tidak ditemukan jentik terhadap jumlah rumah atau bangunan yang diperiksa. Sampai saat ini vaksin dan obat virus DBD belum ditemukan, sehingga salah satu strategi utama dan paling efektif untuk pengendalian penyakit DBD adalah dengan cara melakukan upaya preventif dengan pemutusan rantai penularan melalui gerakan PSN-DBD. Ukuran atau indikator keberhasilan PSN DBD adalah ABJ $\geq 95 \%$ yang diharapkan penularan DBD dapat dicegah atau dikurangi (Kemenkes, 2011).

\section{PEMBAHASAN}

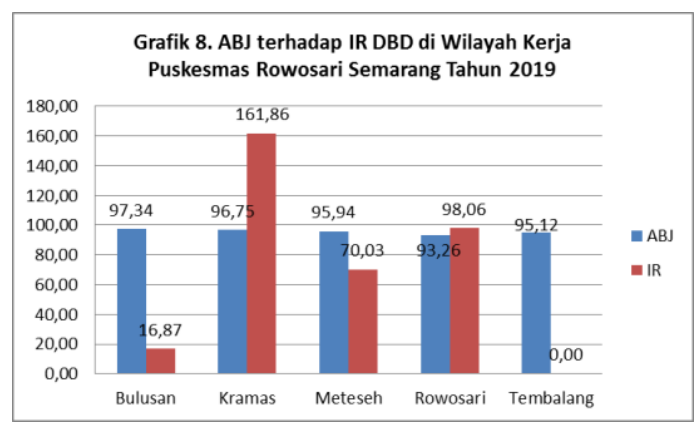

Grafik ABJ terhadap IR DBD terlihat bahwa besarnya $\mathrm{ABJ}$ secara diskriptif tidak mempengaruhi kejadian DBD. Kelurahan yang tidak mencapai standar ABJ (minimal 95\%) adalah Rowosari dengan IR DBD cukup tinggi yaitu 98,06/100.000. IR DBD paling tinggi adalah Kelurahan Kramas walaupun ABJ sesuai standar di atas $95 \%$. Sejalan dengan penelitian Murdani (2017) dan Chandra (2019) yang menunjukkan tidak ada hubungan antara $\mathrm{ABJ}$ dengan Kejadian DBD. Hal ini disebabkan antara lain data ABJ berdasarkan data sekunder dari puskesmas dan pengambilan sampel rumah belum dilakukan secara rutin. Menurut Petunjuk Teknis dari Kemenkes, ABJ didapatkan pada saat Pemeriksaan Jentik
Berkala (PJB) yang dilakukan secara berkala minimal 3 bulan sekali oleh masingmasing puskesmas terutama di desa/kelurahan endemis (cross check) pada tempat-tempat perkembangbiakan nyamuk Aedes aegypti di 100 sampel rumah/bangunan yang dipilih secara acak serta diulang untuk setiap siklus pemeriksaan (Murdani, 2017).

Rekomendasi program pencegahan dan pemberantasan penyakit DBD untuk Puskesmas Rowosari Semarang adalah sebagai berikut:

1. Meningkatkan kepedulian masyarakat terhadap DBD.

2. Membangun kepercayaan, dengan menjadikan masyarakat bukan lagi sebagai obyek melainkan subyek yang akan melaksanakan program.

\section{SIMPULAN}

Kajian epidemiologi Penyakit DBD berdasarkan aspek orang, tempat, dan waktu dapat digunakan untuk pembuatan kebijakan dan sasaran intervensi kesehatan masyarakat. Kejadian DBD di Wilayah Kerja Puskesmas Rowosari banyak terdapat pada penduduk laki-laki (56\%) dan kelompok umur terbanyak $(65 \%)$ adalah 5 - 14 tahun. Kelurahan dengan IR DBD tertinggi (161,86/100000) adalah Kelurahan Kramas. Puncak kejadian DBD adalah Bulan April - Mei pada tahun 2019.

Berdasarkan kajian epidemiologi DBD tersebut, maka disarankan agar terus melaksanakan kegiatan PSN bekerja sama dengan gasurkes. Pecegahan gigitan nyamuk lebih ditingkatkan kepada penduduk usia sekolah. Kegiatan PSN tidak hanya terbatas di lingkungan dalam rumah, tetapi juga lingkungan luar seperti tempattempat umum, lahan-lahan dan rumah kosong. Program kerja bakti membersihkan lingkungan sekitar perlu dimaksimalkan misalnya dengan Kegiatan Jumat Bersih.

\section{DAFTAR PUSTAKA}

Chandra, Emilia. 2019. Pengaruh Faktor Iklim, Kepadatan Penduduk dan Angka Bebas Jentik (ABJ) Terhadap 
Kejadian Demam Berdarah Dengue (DBD) Di Kota Jambi. Jurnal Pembangunan Berkelanjutan, Volume 1. no (1) 2019.

Dahlan, Sopiyudin. 2011. Statistik untuk Kedokteran dan Kesehatan. Jakarta : Penerbit Salemba Medika.

Dinas Kesehatan Provinsi Jateng. 2018. Profil Kesehatan Provinsi Jawa Tengah. http://dinkesjatengprov.go.id/v2018/ dokumen/profil_2018/mobile/index. html. Diakses 19 Oktober 2019.

Dinas Kesehatan Kota Semarang. 2018. Profil Kesehatan Kota Semarang Tahun 2018. http://dinkes.semarangkota.go.id/ass et/upload/Profil/Profil\%20Kesehata n\%202018.pdf.

Diakses 19 Oktober 2019

International Conference of Public Health. 2019. Peran Epidemiologi.http://theicph.com/id ID/id ID/icph/peran-epidemiologi/. Diakses 23 Oktober 2019

Kemenkes RI. Kemenkes Imbau Seluruh Daerah Siaga DBD. 2018 http://www.depkes.go.id/article/vie w/19011800001/kemenkes-imbauseluruh-daerah-siaga-dbd.html. Diakses 19 Oktober 2019.

Kemenkes RI. (2011). Modul Pengendalian Demam Berdarah Dengue. Jakarta: Ditjen PP\&PL Kementerian Kesehatan RI.

Murdani, Agus Putra, et al. 2017. Pemetaan Kejadian DBD Berdasarkan Angka Bebas Jentik dan Jenis Infeksi Virus Dengue.

https://jurnalonline.lppmdianhusada. ac.id/index.php/jkk/article/viewFile/ 39/18. Diakses 25 Oktober 2019.

Permatasari, Rizkina dan Nanda Aulina Rumana. 2018. Gambaran Karakteristik Pasien Demam Berdarah Dengue Rawat Inap di
Rumah Sakit Patria IKKT pada Bulan April 2018 - Agustus 2018. Rekam Medis dan Informasi Kesehatan Jakarta, Fakultas Ilmuilmu Kesehatan Universitas Esa Unggul.

Pusat Data dan Informasi Kemenkes RI. 2017. Situasi Penyakit Demam Berdarah di Indonesia Tahun 2017.http://www.depkes.go.id/articl e/view/19011500007/situasipenyakit-demam-berdarah-diindonesia-tahun-2017.html. Diakses 19 Oktober 2019.

Salsabila, Nurina, dan Bambang Budi Raharjo. 2018. Kinerja Petugas Surveilans Kesehatan dalam Upaya Penanggulangan Demam Berdarah Dengue. Higeia Journal Of Public Health Research And Development. https://journal.unnes.ac.id/sju/index.php /higeia. Diakses 29 Oktober 2019.

Suryani, Endah Tri. 2018. Gambaran Kasus Demam Berdarah Dengue Di Kota Blitar Tahun 2015 - 2017. Jurnal Berkala Epidemiologi, Volume 6 Nomor 3 (2018) 260-267. http://journal.unair.ac.id/index.php/JBE/ . Diakses 20 Oktober 2019.

Syahria, Dian, et al. 2015. Pemetaan Penyebaran Penyakit Demam Berdarah Dengue dengan Geographic Information System di Minahasa Selatan. Jurnal Kedokteran Komunitas dan Tropik: Volume III, nomor 2, April 2015.

Wikrama, Pande Komang Gede Pandu. 2019. Karakteristik penderita suspect demam berdarah dengue berdasarkan penurunan trombosit di Instalasi Rawat Inap Puskesmas Tegalalang I Tahun 20142015. Intisari Sains Medis 2019, Volume 10, Number 2: 301-305. http://isainsmedis.id/. Diakses 20 Oktober 2019.

Wowor, Ribka. 2017. Pengaruh Kesehatan Lingkungan terhadap Perubahan Epidemiologi Demam Berdarah di Indonesia. Jurnal e-Clinic (eCl), Volume 5, Nomor 2, Juli-Desember 2017 